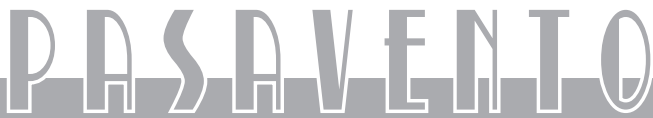

Revista de Estudios Hispánicos

Vol. I, n. ${ }^{\circ} 1$ (invierno 2013), pp. 95-109, ISSN: 2255-4505

\section{"LA TARDE DEL DINOSAURIO" DE CRISTINA PERI ROSSI, UN RELATO FANTÁSTICO}

Ana Prieto Nadal Universidad Nacional de Educación a Distancia

\section{INTRODUCCIÓN}

Nos proponemos revisar aquí una escritura inscribible -seguramente, no sin polémica- en el ingente territorio de lo fantástico, el relato "La tarde del dinosaurio", perteneciente al libro de título homónimo de la escritora uruguaya Cristina Peri Rossi, publicado por vez primera en 1976 y recientemente reeditado. La autora, en su prólogo a la última edición de La tarde del dinosaurio, declara:

Tuve que volver a leer el libro [...] entonces me sucedió una cosa curiosa: tuve deseos de escribirlo otra vez, fuertes, vehementes, deseos. No quería modificarlos, ni cambiar una frase o una palabra, todo lo contrario: quería volver a escribir cada relato otra vez, de manera idéntica, para recuperar las emociones que sentí, el aliento lírico, la ironía, el humor, los contrastes: en busca del tiempo perdido. (Peri Rossi 2008: 9-10)

Julio Cortázar, en su prólogo a la edición original de La tarde del dinosaurio (1976) -prólogo igualmente incluido en la última edición (2008)-, incorporaba a la escritora uruguaya, sin necesidad de preámbulos ni argumentaciones teóricas, a la relación de cuentistas de lo fantástico, del mismo modo que señalaba la "hermosa opción" de la autora, consistente en "proyectar a planos imaginarios 
un contenido histórico, trágicamente real, que no solo guarda su sentido más preciso, sino que multiplica su fuerza en la otra imaginación, la de ese lector que ahora entra en la casa" (2008: 13).

Frente a definiciones más canónicas o restrictivas de lo fantástico, aquí seguimos de preferencia, en virtud de afinidades - de vida y obra- bien conocidas entre Peri Rossi y el escritor argentino, la teoría de Julio Cortázar, quien apuesta por una idea "viva" del cuento -significación, tensión, intensidad, apertura y extrañamiento son algunos de sus postulados (1993: 385-386)- y afirma que lo fantástico es abierto y forma parte de la realidad: a veces, por un corrimiento de esta realidad, acertamos a verlo, a intuirlo; otras veces lo fantástico nos invade, nos visita: "Lo fantástico fuerza una costra aparencial [...] hay algo que arrima el hombro para sacarnos de quicio" (Cortázar 2002: I, 74). Jaime Alazraki acuñó el término de "neofantástico" para referirse a la escritura de algunos autores del siglo xx, tales como Kafka, Borges o Cortázar, y a los sentidos oblicuos, metafóricos o figurativos de que es portadora:

Son, en su mayor parte, metáforas que buscan expresar atisbos, entrevisiones o intersticios de sinrazón que escapan o se resisten al lenguaje de la comunicación, que no caben en las celdillas construidas por la razón, que van a contrapelo del sistema conceptual o científico con que nos manejamos a diario. (Alazraki 2001: 277)

Lo que se persigue es una ampliación de las posibilidades de lo real y de la percepción del lector. Se da, a lo largo del siglo xx, en el terreno de la literatura fantástica, un proceso de cotidianización (Roas 2011: 122), y también un cambio fundamental: el paso de lo fantástico como fenómeno de percepción a lo fantástico como fenómeno de escritura, de lenguaje, generándose la transgresión fundamentalmente a partir de recursos formales y discursivos, más que a nivel semántico (Campra 2001: 97). Seguimos a Martha J. Nandorfy en su afirmación de que la etiqueta literatura fantástica no puede reducirse a una fórmula: "Lo fantástico ensancha los angostos confines de la realidad racional y desestabiliza el lenguaje al jugar poéticamente con él, convirtiendo en metáforas expansivas lo que eran dicotomías reductivas" (2001: 259). Una clasificación rigurosamente extremada, de corte estructuralista, reportaría limitaciones en la captación de lo fantástico, noción que escapa de suyo a toda acotación demasiado rígida.

\section{Cristina Peri Rossi y la literatura de lo imaginario. La tarde del dinosaurio}

La narrativa latinoamericana de los años 60 y 70 cuenta con una producción copiosa, variada y disímil; muchos de estos autores coinciden en aunar ludismo, crítica y desacralización, así como en potenciar la imaginación y lo simbólico en detrimento de una notación estrictamente realista. Ángel Rama (1966: 30) habla, a propósito de esta tendencia narrativa en Uruguay, de una literatura imaginaria o literatura de la imaginación, que no sería un subgénero de lo fantástico sino un producto de la libertad y capacidad de invención que se manifiestan en el aspecto sintáctico del texto literario. Esta literatura de la imaginación 
comparte algunos elementos con lo fantástico -como la ruptura de las leyes de causa y efecto, o la transformación del mundo cotidiano en un mundo extraño-, pero, a diferencia de la literatura fantástica, no se funda en la duda textual ni en el temor producido por el texto en el lector, sino que parte de la aceptación del evento extraordinario (Olivera-Williams 1993: 175).

En esta línea de análisis, Mabel Moraña considera que la narrativa de Peri Rossi se concreta a partir de una "combinación de registros -histórico, cultural, cotidiano, lúdico, onírico, erótico- creando un espacio ficticio en el que coexisten, como en un ámbito surreal, elementos disímiles que aluden alternativamente a la realidad y a la imaginación" (1987: 38). En efecto, el fraseo lúdico de su obra "constituye un acto de apertura, un ejercicio de plena libertad [...]. El juego es, en fin, un intento de reconciliación con el mundo, bajo nuevas banderas" (Verani 1984: 31).

Sin menoscabo de su talante lírico y lúdico, la literatura de Cristina Peri Rossi va indefectiblemente unida a la temática existencial. Tal filiación revelan, en efecto, sus primeros relatos de Viviendo (1963): las preocupaciones estéticas se fundamentan en problemas metafísicos, más allá de los problemas sociales y políticos, aun cuando tempranamente expresa sus convicciones políticas y apuntala firmemente su militancia como una opción de vida. Los museos abandonados obtuvo el Premio de los Jóvenes, de la editorial Arca, en 1968, y fue publicado en 1969; este libro de relatos estaba dedicado expresamente al Hombre Nuevo y se articulaba, sin grandes aspavientos panfletarios, a partir de una alegoría de lo más efectiva. Además de estas obras, Cristina Peri Rossi publicó en Uruguay la novela El libro de mis primos (1969), los textos de Indicios pánicos (1970) y el libro de poemas Evohé (1971). La actividad literaria de Peri Rossi es constante: la autora, que vive en Barcelona desde 1972, ha publicado con asiduidad también en los años 80 y 90 (Redondo Goicochea 2001: 159) y en la primera década del siglo xxı.

La tarde del dinosaurio pertenece a la etapa del exilio y fue publicada en Barcelona, lugar de destino de la autora, en 1976. Peri Rossi declara que "el exilio ha sido una reflexión obligada sobre lo otro" (San Román 1992: 1042). La experiencia del exilio está presente en buena parte de la literatura de Peri Rossi ${ }^{1}$ - La nave de los locos (1984) es sin duda el paradigma de esta presencia temática, como también los poemarios Descripción de un naufragio (1974) y Diáspora (1976), entre otros- y lo está también en varios cuentos del volumen que nos ocupa, La tarde del dinosaurio. Así, "En la playa", una pareja que está de vacaciones trata paternalmente de ayudar a una niña extranjera, solitaria y autosuficiente que acaba invirtiendo la situación y consintiendo en velar para que los adultos no tengan miedo. En "La influencia de Edgar Allan Poe en la poesía de Raimundo Arias", la protagonista es nuevamente una niña, Alicia, inteligente y obsesionada con los "barcos llenos de horas robadas, barcos silenciosos que atravesaban el mar con su carga secreta de tiempo" (Peri Rossi 2008: 59); una niña que -en clara inversión de la situación de normalidad-protege a su padre, un intelectual que

\footnotetext{
${ }^{1}$ Para el estudio e interpretación de la literatura del exilio de Cristina Peri Rossi, véase el artículo de María Rosa Olivera-Williams (2012), que vincula el cuestionamiento del lenguaje con la querella simbólica, existencial e histórica entre el arraigo y el desarraigo.
} 
se ve obligado a vender jabones para subsistir, en el exilio forzoso que les ha tocado vivir.

La autora declara que "El exilio fue una pasión, tan fuerte como el amor, porque para los obsesivos, lo importante es la pulsión, no el objeto. De modo que, cuando el exilio acabó, busqué otra dictadura, la del amor" (Peri Rossi 1993: s. p.). La temática amorosa es central en la obra de Peri Rossi-Una pasión prohibida (1986), Solitario de amor (1988), Babel bárbara (1990) y El amor es una droga dura (1999), por citar solo algunas obras- y la hallamos ya en estos relatos de 1976.

La sensualidad se despliega de modo amplio y polimorfo en algunos relatos de La tarde del dinosaurio, siendo "De hermano a hermana" -ensueños de incesto de un chico que se recrea contemplando en la playa la "lascivia cadenciosa, un sigilo de pantera, perezosa lujuria" (Peri Rossi 2008: 19) de su hermana mayor-y sobre todo "Simulacro" -amor no correspondido en la luna-, "Gambito de reina" y "La historia del príncipe Igor", los cuentos donde la presencia del erotismo es más evidente. La fusión de mundo onírico y vigilia -a la manera de Chuang-Tzú, que "soñó que era una mariposa y no sabía al despertar si era un hombre que había soñado ser una mariposa o una mariposa que soñaba ser un hombre" (Borges 1967: 5), y del relato borgiano "Las ruinas circulares" (1941)- es la premisa para sembrar "La historia del príncipe lgor" de espejos que engullen y emanan sueños -espejos como "lunas cansadas, lunas que han divagado, vagado lejos"-, damas milenarias que exhalan "un rancio perfume / antiguo y procaz" (Peri Rossi 2008: 143) y que danzan con túnicas grises que se deshilvanan como hojas secas, trituradas, con trajes de piedra que sueltan polvo, "un rastro tenue y muy volátil, efímero, cuyo espectro iba del gris al rojo" (Peri Rossi 2008: 144). Lo imaginario irrestricto es condición asimismo para asistir a la insaciable sensualidad de Alejandra en "Gambito de reina", la abeja reina que nunca perderá la partida porque juega sin rey y que yace con Mnasidika, la niña-árbol, la virgen efebo (Peri Rossi 2008: 133), llamada en ocasiones Hylas, como el joven siervo y amante de Hércules que fue seducido por las ninfas de la fuente y se quedó para siempre con ellas. El erotismo del cuerpo y de la palabra domina en estos relatos, dentro del mismo impulso lúdico -"Desflorar el idioma: Eros ludens" (Yurkievich 1978: 14)- de naturalizar y desinhibir el cuerpo y el deseo, ya presente en aquella certera hipálage doble de su primer poemario, Evohé: "La mujer pronunciada y la palabra poseída" (Peri Rossi 2005: 67).

El lenguaje de Peri Rossi, de gran lirismo y plasticidad, dibuja nubes lilas que se desplazan por el cielo "como antiguas matronas" (Peri Rossi 2008: 89) y mujeres de "costados morborescentes" (Peri Rossi 2008: 163); es atinado y sugerente, con "palabras obscenas [...] como barcos pesados" (Peri Rossi 2008: 144), dotado de precisión y a la vez recubierto de un vaho espeso que evoca placeres difusos y voluptuosidades sin cuento. La obsesión por el lenguaje es la obsesión por la lógica y la poética del mundo, y en estos cuentos los niños lo mismo se refieren al título de un libro de Ciro Alegría (El mundo es ancho y ajeno) que a uno de Susan Sontag (Contra la interpretación). Por otra parte, nombres de la mitología y de la historia más arcana asoman casi de puntillas por estas páginas: se 
nombra a Hylas y también a Hércules, con quien se compara al estudiante Mario, enamorado de Alina, en el cuento "De hermano a hermana"; Albumazar, astrónomo árabe del siglo Ix, y su maestro Alchindius, filósofo, científico y polígrafo árabe al que se atribuye El libro del sueño y de los sueños, aparecen como personajes del relato "La historia del príncipe Igor". En "Gambito de reina" se cita al poeta francés del siglo xv François Villon y, en otro orden de cosas, el número áureo del hombre de Vitruvio explica, en el mismo relato, la relación entre la cantidad de abejas macho y abejas hembra en un panal; por eso -se nos dice- los zánganos no tienen padre y viven sin arma, envaginados, "en una interminable cópula nupcial" (Peri Rossi 2008: 141).

Declara Cristina Peri Rossi que la suya es una literatura claramente simbólica, y que procura establecer un universo alegórico (Mattalía 1994: 48). El modelo alegórico que siguen muchos de sus textos "formaliza la actividad interpretativa creando una dialéctica que une el microuniverso factual y cotidiano con representaciones macrocósmicas o imágenes que globalizan la experiencia del individuo" (Moraña 1987: 39). Comenta asimismo Peri Rossi que los relatos, "cuando son simbólicos, tienen una sola posibilidad. Ya están escritos. En cambio, si son líricos, te permiten todo tipo de juego. Y lo lírico y lo lúdico están muy cercanos" (San Román 1992: 1044).

Con su escritura plural y proteica, su prosa minuciosa y connotada, su alta tensión lírica y su polisemia abierta a interpretaciones alegóricas más allá de las soluciones únicas, la obra de Cristina Peri Rossi confirma la supremacía de la imaginación y de la palabra poética, revela lo intersticial y permite el acceso a otras frecuencias de la realidad.

\section{La alteridad polisémica en "La tarde del dinosaurio"}

A diferencia de otros relatos del mismo libro, como los ya mencionados "Gambito de reina" o "La historia del príncipe Igor", cuyo tejido poético y surreal remite más bien a una realidad textual autónoma en la que se amplían los límites de lo real al borrarse la frontera con lo irreal -todo es posible y asumible sin extrañamiento-, "La tarde del dinosaurio" se inscribe con total legitimidad, a nuestro modo de ver, en el género de lo fantástico.

La mayor parte del relato la ocupa un discurso de corte realista cuyo cometido es darnos a conocer las coordenadas vitales -mentales- del niño protagonista y que produce, con su centralización del relato, la dilación del elemento fantástico, que actúa al final del cuento con la intrusión del ámbito del sueño en el de la vigilia. Así, lo fantástico es aplazado en virtud de una sabia diseminación de motivos y resortes a nivel de lo temático y de lo sintáctico. Los dos elementos que configuran el título se encuentran alejados en el texto: la "tarde" se instala ya desde la primera página, mientras que la mención del "dinosaurio" no sobreviene hasta bien entrada la narración. Por la tarde -principia el relato-, el niño baja a la playa con una expectativa que no se concreta entonces y que se reanuda en ese mismo escenario en el tramo final del cuento. Así pues, lo fantástico se desanuda más tarde, se posterga, y lo que media entre esta primera bajada 
a la playa y el desenlace final no es sino una enorme digresión explicativa que favorece una interpretación simbólica, adensada y multiplicada por el lirismo y el instinto lúdico, y que sugiere ese sentido oculto -esa otra realidad oculta- y en última instancia indescifrable que caracteriza al nuevo relato fantástico. Acaso se proponga el discurso realista abrir brechas posibles, conflictos potenciales que, en virtud de una rara mezcla entre lo causal y lo intuitivo, permitan alegar las hipotéticas y un tanto paradójicas razones de lo fantástico; ya no el qué, que sería lo puramente fantástico, sino el porqué, la interpretación derivada de la lectura. Denota asimismo una voluntad de desorientar al lector, que se distrae en detectar posibles motivos psicológicos, lo mismo que sociológicos, esto es, explicaciones exotéricas que acaso trasciendan la intención de la autora: "Yo lo psicológico lo siento demasiado como para tener ganas de enchastrarme los dedos con eso. Lo percibo demasiado. Para mí no forma parte de lo imaginario, y a mí me interesa más lo imaginario" (Peri Rossi en San Román 1992: 1045). En este tira y afloja entre un retorno opresivo y la vía de escape resulta particularmente operativa la teoría freudiana de lo fantástico como revenant: el contenido replegado en el inconsciente, las pulsiones reprimidas regresan convertidas en algo extraño, desconocido, perturbador.

En "La tarde del dinosaurio" asistimos al mundo escindido y complejo de un niño característico de la narrativa de Peri Rossi, un niño que subvierte la relación protectora del padre respecto del hijo, un niño que es casi como un adulto, custodio de su padre número uno y crítico con su padre número dos. Un niño asimismo obsesionado con el lenguaje, cortado por el mismo patrón que, por ejemplo, la niña del relato "En la playa". Los niños que aparecen en la obra de Peri Rossi son sabios y visionarios, a menudo dedicados al cuidado de unos padres que no son sino "falsos adultos" (Cortázar 2008: 13), unos padres estremecedoramente indefensos. No se nos precisa la edad del personaje, pero debe de estar probablemente en el umbral de la adolescencia y deja entrever notables crisis existenciales -"Nunca había pedido que lo trajeran al mundo, no había podido elegir el año, ni la época, ni el país" (Peri Rossi 2008: 97)-, así como una temprana visión crítica de la historia y del poder. La oposición que establece entre su padre número uno, intelectual fracasado y caótico, y su padre número dos, ejecutivo en ascenso, deviene equiparable a la dialéctica cortazariana del cronopio y el fama. El padre número uno es el desposeído, el absurdo, un pobre diablo; el otro es el capitalista, el que no importa que se muera porque es puro trámite. Ninguno de los dos es capaz de ofrecer alternativas a una realidad que se revela insatisfactoria, insoluble; la opción personal del niño no puede, ante esto, ser otra que la del repliegue interior, la evasión. Concluye el niño: "No pienso comprar ese ni ningún otro tipo de futuro" (Peri Rossi 2008: 100). De rechazo, se acoge a un pasado primitivo y legendario, entre atavismos y fabulaciones brontosáuricas. El relato entero es atravesado por una crítica sistemática y recurrente de la tecnocracia: "Aun en los países subdesarrollados y atrasados como ese, las máquinas podían realizarlo todo" (Peri Rossi 2008: 90); y de la educación: "En la escuela se pasaban enseñándole cosas inútiles" (Peri Rossi 2008: 89). Se patentiza un odio enconado 
contra la sumisión, la Obediencia, nombre con que el niño bautiza la máquina que es el orgullo de su padre número dos:

\begin{abstract}
La máquina parecía un soldado, rígido y lleno de latas, disciplinado, un soldado que sólo cumplía órdenes, sin discutir, sin pensar; un soldado construido, como todos, para seguir las instrucciones, los planes de los que mandan, un soldado exento de reflexión, pero adoctrinado, programado, útil para servir y para callar. (Peri Rossi 2008: 105)
\end{abstract}

Estos fragmentos contienen y desempeñan funciones indiciales -siguiendo la terminología de Roland Barthes (2000)-, que operan suministrando información, claves para la comprensión del texto, para su ulterior interpretación. No son pocos los datos que vamos acumulando a medida que avanzamos por la extensión material del relato. Se da en "La tarde del dinosaurio" una dinámica de expectativa en que cada indicio puede tomarse por el definitivo, pero todo acaba postergándose, irresoluto. Ahora bien, sin lugar a dudas, el máximo grado de ominosidad lo asume el desconcertante apunte -aparentemente fuera de tono y, por lo mismo, cargado de intencionalidad-sobre un hábito reciente del niño, consistente ni más ni menos que en pintar esvásticas en los pupitres de la escuela; forzosamente esta información ha de estar vinculada de manera directa, insoslayable, a la formulación onírica del dinosaurio y su definitiva intrusión en la vigilia. A lo largo del relato se tematiza una visión o descripción del mundo que no es inocente: la oposición insalvable y parcial entre el padre número uno y el padre número dos, la omisión deliberada de la figura materna -"Su madre. O sea, la esposa de su padre, que ya no era su esposa, aunque seguía siendo su madre. ¿Por qué no podía uno divorciarse de la madre, como había hecho su padre?" (Peri Rossi 2008: 91)-, la alusión a la "guerra pequeñita" (Peri Rossi 2008: 92) de su país y a la aspiración de un país subdesarrollado por incorporarse al progreso, la crítica a la sumisión ante el poder.

El texto se carga de funcionalidad y no conoce frases inocentes: es hiperfuncional y pansignificativo (Campra 1991). Ello no impide que el relato esté lleno de secuencias descriptivas - de la playa, la tarde, el dinosaurio- que no economizan sino que cumplen un objetivo estético irrenunciable, incluso algunas series enumerativas, reiterativas y amplificadoras, que, en opinión de Ángel Rama, remiten a una literatura "informe, usando la palabra en el mismo sentido en que la crítica de arte habla de una pintura informal" (1972: 243), y que, a nuestro modo de ver, se relacionan con el llamado discurso de la abundancia de que habla Julio Ortega (1992) a propósito de la literatura latinoamericana.

Por otra parte, los juegos con el lenguaje, que constituye casi un personaje más en los relatos de Peri Rossi, no son gratuitos; el trabajo con el lenguaje deviene asimismo ominoso. El juego con el idioma -las infatigables enumeraciones en forma de réplicas alternativas y eslabonadas entre el padre número uno y el niño, entre este y su hermana de seis años, niña de asombrosa lucidez y compartida obsesión por el lenguaje- reviste una clara condición o voluntad pesquisidora que permite al niño caminar hacia lo Otro; además, la sugestiva literalidad que manifiesta en su forma de abordar el lenguaje es absolutamente 
fantástica y coadyuva a promover la expectativa de ver qué puerta se abre a partir de una situación lúdica cualquiera, de una confusión de términos cualquiera.

No hay que olvidar que, a fin de cuentas, el texto fantástico "se erige como el lugar y el medio para una crítica del universo de la representación, instaurando por eso mismo un vértigo de la razón desconcertada" (Bozzetto 2001: 224), y ello mediante la subversión de todo discurso fiable y la instalación de una efectiva alteridad. De aquí que lo fantástico en la obra literaria se manifieste, más que por la narración de eventos extraordinarios o sobrenaturales, por la presencia y actuación de fuerzas que apuntan hacia ese otro orden oculto y misterioso. Así, en "La tarde del dinosaurio" no llegamos a saber cuál es la verdadera naturaleza de la fuerza invasora con trazas de dinosaurio cuyo advenimiento el niño aguarda inquieto y expectante.

En virtud del concepto cortazariano de extrañamiento se trasciende la concepción todoroviana de lo fantástico, a saber, la "vacilación experimentada por un ser que no conoce más que las leyes naturales frente a un acontecimiento aparentemente sobrenatural" (1972: 34), si bien Roas (2011: 30) sostiene que lo esencial para que el conflicto genere un efecto fantástico no es la vacilación sino la inexplicabilidad del fenómeno. En Peri Rossi no hay vacilación. En "La tarde del dinosaurio" se da una interpenetración de planos (real y ficticio) que perturba acaso al lector pero no al personaje y que se opera en virtud de la transición constituida ni más ni menos que por la propia expectativa -voluntad-del niño protagonista. Como dice Jaime Alazraki, "lo insólito se presenta [...] como una realidad más, los personajes no revelan ningún asombro, sino más bien enfrentan lo insólito con gran naturalidad" (1983: 29).

El niño del cuento que nos ocupa no solo no muestra asombro ni turbación alguna frente al advenimiento de lo fantástico, que, a decir verdad, no siente como tal, sino que incluso lo espera paciente y seguro de su asistencia. Incorpora así con gran naturalidad el elemento sobrenatural a la realidad íntima de su sentir; es más, lo genera por necesidad. No hay, pues, fractura del continuo, sino organicidad en la experiencia. Contrariamente, esta misma irrupción sí provoca vacilaciones en el lector implícito, cosa que no ocurre en el territorio de lo "maravilloso" -al que podrían adscribirse acaso relatos antes aludidos, como "Gambito de reina" o "La historia del príncipe Igor"-, ni en el de lo "extraño", y en esto nos atenemos a las categorías fijadas por Todorov (1972). Recogiendo las directrices fundamentales de Roger Caillois (1970) y Louis Vax (1973), la concepción de lo fantástico que aquí esgrimimos empieza por la irrupción del ámbito de la ficción o sus posibles correlatos en el ámbito de la realidad o sus posibles correlatos. La relativa autonomía de la ficción solo existe en su compleja relación con lo real, actualizando pues la alteridad realidad/ficción o, en el caso concreto de "La tarde del dinosaurio", sus correlatos vigilia/sueño, yo/otro. No hay separación, no hay distancia entre la emergencia fantástica (el dinosaurio) y el yo (el niño). Desde lo extraño llegamos a nosotros mismos.

Ahora bien, cabría preguntarse si se da una verdadera conmoción o hecho fantástico, o no. Ocurre que el cuento fantástico es un artefacto construido en base a una duplicidad básica: por una parte, es un caso o suceso, puro fe- 
nómeno; por otra parte, enigma o adivinanza. En tanto que enigma, el relato exige una respuesta; como caso que es, no la admite (Bessière 2001: 97). De ahí surgiría el desajuste expresivo. El final abierto, abismado, proyecta una potencialidad mucho más sugestiva y efectista que cualquier deixis o enunciación. La materialización definitiva del dinosaurio en "La tarde del dinosaurio", la irrupción de lo otro en la mismidad del niño, pone término al relato, y el grito final del sujeto enajenado deviene oquedad infinitamente suspensa. Compárese el grito que cierra este relato - "¡Papá!" (Peri Rossi 2008: 126)- con la súplica final de "Simulacro II", último texto del volumen: "Piedad -dije" (Peri Rossi 2008: 166). Lo fantástico emerge de la conciencia individual, porque el espacio de lo fantástico es la psique para Cristina Peri Rossi; su relato, crisol donde lo mismo se transforma en lo otro, se endereza hacia la metamorfosis.

Veamos la primera irrupción del motivo del dinosaurio en el relato:

En el sueño, el dinosaurio salía a una hora imprecisa. La espera lo llenaba de inquietud. No sabía por qué, pero sentía la necesidad de controlarlo. Toda esa fuerza y poder sueltos por el mundo eran peligrosos. Solo él podía verlo de lejos, hablarle, impedir que sus enormes brazos rodearan a la gente y que impulsivamente hiciera entrechocar sus cabezas y los arrojara lejos, al fondo del mar [...]. Apaciguarlo. Domesticarlo. Evitar la destrucción. Impedir que atrapara a su padre, a su hermana, a sus amigos. Vigilar su aparición, montar guardia en la cadera del mar, junto a las olas, esperándolo todo el tiempo, como a una revelación. También debía impedir que alguien lo matara al descubrirlo. Era una misión muy delicada. (Peri Rossi 2008: 122-123)

Caillois habla del misterio del sueño y de la actitud del durmiente frente a esa fantasmagoría surgida de su imaginación: "Como se desarrolla sin su consentimiento, le es difícil creerse responsable de ella. Por otra parte, no puede no quedar persuadido de que le está dirigida [...] no duda ser el destinatario privilegiado de una solemne y oculta investidura" (1970: 85). Por otra parte, Cortázar señala que lo verdaderamente fantástico en un relato reside en "su resonancia de pulsación, de latido sobrecogedor de un corazón ajeno al nuestro, de un orden que puede usarnos en cualquier momento para uno de sus mosaicos" (2002: I, 74). La llamada de esa oscura fuerza materializada en el dinosaurio, el reclamo imperativo del sueño, sitúa al niño en otro plano y lo lleva a componer una asombrosa figura.

En "La tarde del dinosaurio" se verifica el recurso a la simbología animal como modo de representación de la alteridad. Se trata, en este caso, de un animal extinguido e imposible. Un monstruo. Pero un monstruo asiduo y cotidiano a fuerza de ser convocado y modelado en sueños: "Dino, monstruo ingenuo, y familiar, compañero de inmersiones en el agua, devorador de hombres, perseguidor de peces; Dino, un amigo particular, un pariente próximo de extraña fisonomía" (Peri Rossi 2008: 111). Un monstruo temible por la carencia de nociones morales, no por maldad intrínseca: "Emerge con ingenuidad e inocencia, sin sensación de culpa. Emerge inmensa y castamente, como un enorme muñeco loco. Como un elefante enfermo. Y jugar con los hombres es un pasatiempo benigno 
e inofensivo para él" (Peri Rossi 2008: 110). Un monstruo niño -"curioso bebé en su bañadera portátil" (Peri Rossi 2008: 124)- para un niño demasiado adulto que se adjudica el desempeño de una tarea, poco menos que una misión: impedir el mal, "evitar la destrucción" (Peri Rossi 2008: 123). No tiene existencia objetiva, es producto del sueño, pero se diría que la fuerza del sueño y de la voluntad tiene la capacidad de hacerlo emerger de las aguas: "Él lo invadía sin permiso, es verdad, pero ya se había acostumbrado tanto a sus irrupciones nocturnas, a su sonámbula aparición en medio del sueño, que era como un antepasado querido, un abuelo legendario, un navegante noruego varado en la isla del sueño" (Peri Rossi 2008: 123-124). El dinosaurio es otro yo remoto e incognoscible, un doble precario que acaso quiera remitir al microrrelato de Augusto Monterroso (1959) - "Cuando despertó, el dinosaurio todavía estaba allí"-, de donde habría escapado para ser traspuesto, amplificado e incluso alegorizado. Lo ominoso como el regreso de lo reprimido, rechazado por el yo, el monstruo arcano aherrojado en el inconsciente.

Sabemos que el monstruo es un arquetipo narrativo de la otredad, un discurso narrativizado sobre la relación entre el Yo y el Otro (Moreno Serrano 2011: 476). El monstruo, lo irracional, lo desconocido, habita en nosotros. Se relaciona directamente con lo más íntimo, con nuestra identidad. El monstruo "representa nuestras tendencias perversas y homicidas; tendencias que aspiran a gozar, liberadas, de una vida propia. En las narraciones fantásticas, monstruo y víctima simbolizan esta dicotomía de nuestro ser" (Vax 1973: 11). Pero, si bien este dinosaurio soñado que emerge de las aguas rompe con lo admisible dentro de un sistema, conlleva un germen de destrucción y produce rechazo o negación, no resulta siniestro. Es percibido como una difusa amenaza que el niño entiende o contiene en sí mismo, pero es tierno y entrañable, un arcano que apela al atavismo -frente a la tecnología que representaría la máquina del padre número dos, direccionada hacia el futuro. "El monstruo es la proyección del otro que me habita", dice Cortázar (1995b: 36). No se trata de un monstruo prospectivo, "imposible en nuestra sociedad actual, pero plausible según las reglas de nuestro mundo empírico y que es empleado como herramienta retórica para profundizar en inquietudes culturales del ser humano" (Moreno Serrano 2011: 477), sino que es más bien -si se nos permite- un monstruo analéptico, retrospectivo, que emerge del pasado, implausible y monumental.

Señala Víctor Bravo que "el drama de toda cultura es el intento de reducir lo irreductible, la alteridad, hacia la tranquilidad ideológica de lo Mismo, de la Identidad. La alteridad parece ser lo insoportable" (1987: 16). Esta dialéctica entre alteridad y lo mismo, que toda cultura dramatiza, tiene su primera evidencia en la producción de los discursos. Lo fantástico en literatura es el territorio donde la alteridad como elemento productivo ${ }^{2}$ del texto entra en escena. Lo otro, en "La tarde del dinosaurio", intenta ser domesticado con palabras por el niño, pero es indecible e indomesticable. "Lo otro sigue estando presente, opaco, viscoso,

\footnotetext{
${ }^{2}$ Tomamos de Julia Kristeva (1981) el concepto de productividad, entendido este como el conjunto de mecanismos discursivos que hacen posible el hecho estético.
} 
en el umbral de lo representable" (Bozzetto 2001: 237). Comparte con lo sagrado que es fascinante y tremendo.

Está también el tema de la exorcización. La transmigración de un hombre en axolotl en el relato cortazariano "Axolotl" (Cortázar 1995a) describe simbólicamente ese proceso por el cual la obsesión queda atrapada del otro lado y trocada en imagen poética: "Desde un primer momento comprendí que estábamos vinculados, que algo infinitamente perdido y distante seguía sin embargo uniéndonos" (Cortázar en Rosenblat 1990: 103). "La tarde del dinosaurio" termina con el grito del niño ante el dinosaurio y su híbrida -nueva y antigua a la vez-condición de fósil animado y gigantesco que, una vez materializado, no podrá ser contenido ni frenado:

Él lo esperó, concentrando toda su energía en mirar, en esperar, pero tembloroso. ¿Qué noche era esa noche insensata de revelaciones? Una noche como un desfiladero. Una noche como un hormiguero negro. Confió en no claudicar.

Y cuando el enorme aparecido,

el sigiloso,

el brontosaurio apocalíptico estuvo cerca, quedamente, miró hacia la casa, y gritó:

- ¡Papá! (Peri Rossi 2008: 126)

Para Bravo (1987: 47), la producción de lo fantástico supone la escenificación del Mal, entendido este en su sentido funcional, más que ético. Cortázar vislumbra, en ese mar de donde emerge la figura del brontosaurio, el horizonte de la oscura, temible adolescencia, así como una denodada negativa de ingresar en el mundo de los adultos, o de los falsos adultos: "el adolescente se vuelve hacia su pasado en una última, desesperada resistencia; pero su sexo y su pelo y su voz lo arrastran al vértice que el muchacho del dinosaurio contempla con horror final" (2008: 13). El último grito del chico -o del dinosaurio, pues ambas voces están deliberadamente confundidas-, la mirada llena de terror hacia la casa en busca de la figura paterna, ¿es puro miedo y búsqueda de protección? ¿Es voluntad de protección hacia una figura paterna que siempre se ha visto indefensa e inerme? ¿Corresponde a una súbita pero impostergable certeza de que el padre corre peligro, acaso por una profunda transformación acontecida en el lado más oscuro del muchacho? ¿Es el propio chico la amenaza? ¿Su ego más recóndito? ¿Su alteridad más inconfesa, la misma que lo hace pintar esvásticas en los pupitres? El dinosaurio es una prolongación de sí mismo, un amigo imaginario hecho a base de sueños, una recurrencia primero involuntaria que después el chico habría anhelado convocar con más fuerza cada vez, casi -se nos antoja- modelando concienzudamente su imagen, esculpiendo con la imaginación las escamas - plateadas y "prominentes como gigantescos pétalos de flores" (Peri Rossi 2008: 110)-, escogiendo su color, forma y textura, del mismo modo como aquel personaje -de filiación surrealista-, del autor alemán Michael Ende, "se había soñado alas [...] pluma por pluma, músculo por músculo y huesecillo por huesecillo en largas horas de trabajo, de sueño, hasta que tomaron forma" (1993: 8). El dinosaurio aglutina la perversidad ancestral, primitiva, congénita, en 
cierta forma inocente - ¿inconsciente?- y por lo mismo impune, del ser humano. Este salto de lo individual a lo social lo hallamos en varias ficciones de Peri Rossi, en que la autora "traduce a imagen el concepto, dramatiza simbólicamente las tensiones y traumas de la sociedad representada, alegorizando en términos fantasiosos e irrestrictos, un mundo de clausura" (Moraña 1987: 40). Así, se brinda la "revelación emotivo-valorativa" (Beltrán Almería 2001: 558) que es esperable de un relato y que lo vincula a una función crítica.

El sueño se prolonga en la vigilia. El inicio del relato augura una inminente aparición del dinosaurio emergiendo del mar, realización o actualización del sueño que en el tramo final del relato se hace efectiva: "Lo vio salir de lejos, y tembló de frío [...]. Lo que más le sorprendió fue que el color de sus escamas era exactamente el mismo color que las escamas tenían en los sueños. Grises y plateadas, con un brillo muy intenso" (Peri Rossi 2008: 124). No hay respuestas, solo preguntas, y una inquietud de fondo. Una certeza oscura. Un secreto imposible de desvelar. El dinosaurio: el elemento significativo, la cristalización de un sentido otro -poético, alegórico- que no se evidencia en el texto como una fijeza ni como una reducción unidimensional del sentido sino como una apertura, como una poética.

\section{A MODO DE CONCLUSIÓN}

Inmensa, interminable tarea la de clasificar lo fantástico, estatuirlo, inventariarlo. Lo fantástico es un ente fluido, así como la puesta en escena de la alteridad. Un determinado tipo de literatura fantástica "en lugar de disolver o vaciar la realidad, disuelve las cesuras de los sistemas binarios, que separan la experiencia del pensamiento y lo fantástico de la realidad" (Nandorfy 2001: 260). En "La tarde del dinosaurio" prevalece la aspiración y el empeño de socavar las viejas dicotomías, de volver inoperantes las distinciones estructurales y lógicas entre lo mimético, lo fantástico y lo maravilloso. De romper la torpe máquina binaria, como dice Yurkievich: "conjunciones en vez de disyunciones [...] mutaciones reversibles [...] máxima polisemia" (1978: 13).

"La tarde del dinosaurio" es la noche insensata de revelaciones en que tiene lugar la asunción definitiva por parte del niño de su condición brontosáurica en convivencia con la humana. Lo otro que buscamos apaciguar, domesticar, concebir como un ser inocente y entrañable, un poco a la manera del padre número uno. Lo otro, un monstruo que da sus primeros pasos, como en un vacilante ingreso a la edad adulta: "Se asombraba de poder caminar sobre el mar, de mover las costras de piedra del lomo" (Peri Rossi 2008: 125). El estremecimiento singular que para Vax debe producir lo fantástico ocupa el final del cuento. El desdoblamiento y la metamorfosis son también expresión poética de una urgencia existencial y de una necesidad de borrar los límites que nos separan de lo otro. En el prólogo a la reedición de la obra, declaraba la autora: "Solo se puede seguir escribiendo si se olvida lo que se ha escrito; si se lo recuerda, una se condena a la repetición. Yo lo escribí, lo olvidé y al leerlo, volví a escribirlo" (2008: 10). Nosotros celebramos poder revisitar este relato tan representativo de 
un tiempo y de una poética, haber franqueado la entrada para descubrir otras puertas "que no han sido fabricadas en la carpintería de la ciudad diurna" (Cortázar 2008: 11), nuevas referencias y mundos, asociaciones y reverberaciones ensoñadas. Asomarnos a ese territorio onírico y lunar, meloso y mélico, marino y brontosáurico que es la escritura de Cristina Peri Rossi, cargada de intensidad emocional y escandida con pulso lírico. Asistir al advenimiento de la alteridad -extranjería, irrealidad- que acude, con toda su carga de ternura y de amenaza, a desestabilizar el mundo monológico de la racionalidad. Lo intranquilizador, lo misterioso, los sueños y pesadillas, el erotismo, las energías transgresoras se expresan a través de lo fantástico y de la poesía. La fusión entre el mundo de los sueños y la vigilia: "Mi ajenidad / -soy la extranjera, la de paso- / es la ciudadanía universal de los sueños" (Peri Rossi 2003: 74). En la literatura de Cristina Peri Rossi halla un espacio propicio la reivindicación de la libertad imaginativa que desboca los aledaños del realismo y revela una realidad más compleja y rica, con el énfasis puesto en la intuición, el sueño y lo irracional, tres instancias cardinales en la fundación de lo fantástico. El universo fantástico es un universo abierto, pues las leyes que lo rigen son desconocidas.

\section{OBRAs CITADAS}

Alazraki, Jaime (1983): En busca del unicornio. Los cuentos de Julio Cortázar. Elementos para una poética de lo neofantástico. Madrid, Gredos.

— (2001): "¿Qué es lo neofantástico?". En: Roas, David (ed.): Teorías de lo fantástico. Madrid, Arco/Libros, pp. 266-282.

Barthes, Roland (2000): Mitologías. Madrid, Siglo xxı.

Beltrán Almería, Luis (2001): "Pensar el cuento en los noventa". En: Romera Castillo, José y Gutiérrez Carbajo, Francisco (eds.): El cuento en la década de los noventa. Madrid, Visor, pp. 547-560.

Bessière, Irène (2001): "El relato fantástico: forma mixta de caso y adivinanza". En: Roas, David (ed.): Teorías de lo fantástico. Madrid, Arco/Libros, pp. 83-104.

Borges, Jorge Luis (1941): El jardín de senderos que se bifurcan. Buenos Aires, Sur.

- (1967): La literatura fantástica. Buenos Aires, Ediciones Culturales Olivetti.

Bozzeto, Roger (2001): "¿Un discurso de lo fantástico?". En: Roas, David (ed.): Teorías de lo fantástico. Madrid, Arco/Libros, pp. 223-242.

Bravo, Víctor (1987): Los poderes de la ficción. Caracas, Monte Ávila.

Caillois, Roger (1970): Imágenes, imágenes... Sobre los poderes de la imaginación. Barcelona, Edhasa.

Campra, Rosalba (1991): "Los silencios del texto en la literatura fantástica". En: Morillas Ventura, Enriqueta (ed.): El relato fantástico en España e Hispanoamérica. Madrid, Sociedad Estatal Quinto Centenario, pp. 49-73.

- (2001): "Lo fantástico: una isotopía de la transgresión". En: Roas, David (ed.): Teorías de lo fantástico. Madrid, Arco/Libros.

Cortázar, Julio (1993): "Algunos aspectos del cuento". En: Pacheco, Carlos y Barrera Linares, Luis (eds.): Del cuento y sus alrededores. Caracas, Monte Ávila, pp. 379-396.

— (1995a): "Axolotl". En: Final del Juego. Madrid, Anaya \& Mario Muchnik, pp. 141-146. 
- (1995b): Los Reyes. Buenos Aires, Sudamericana.

- (2002): La vuelta al día en ochenta mundos, 2 vols. México D. F., Siglo xxı.

- (2008): "Invitación a entrar en una casa". En: Peri Rossi, Cristina: La tarde del dinosaurio. Zaragoza, Tropo Editores.

Ende, Michael (1993): El espejo en el espejo. Barcelona, Primera Plana.

González Bermejo, Ernesto (1978): Conversaciones con Cortázar. Barcelona, Edhasa.

Kristeva, Julia (1981): Semiótica 2. Madrid, Fundamentos.

Mattalía, Sonia (1994): "Tensión y alegoría. Cristina Peri Rossi". En: Quimera, n. ${ }^{\circ} 123$, pp. 48-49.

Monterroso, Augusto (1959): Obras completas (y otros relatos). México D. F., UNAM.

Moraña, Mabel (1987): "Hacia una crítica de la nueva narrativa hispanoamericana: alegoría y realismo en Cristina Peri Rossi". En: Revista de Estudios Hispánicos, tomo xxI, n. ${ }^{\circ}$ 3, pp. 33-48.

Moreno Serrano, Fernando Ángel (2011): "El monstruo prospectivo: el otro desde la ciencia ficción". En: Signa, n. ${ }^{\circ} 20$, pp. 471-496. http://descargas.cervantesvirtual.com /servlet/SirveObras/01372731933571217971802/041057.pdf?incr=1. Última visita: 20.08.2012.

Nandorfy, Martha J. (2001): "La literatura fantástica y la representación de la realidad". En: Roas, David (ed.): Teorías de lo fantástico. Madrid, Arco/Libros, pp. 243-261.

Olivera-Williams, María Rosa (1993): "'El derrumbamiento' de Armonía Somers y 'El ángel caído' de Cristina Peri Rossi: dos manifestaciones de la narrativa imaginaria". En: Revista Chilena de Literatura, n. ${ }^{\circ}$ 42, pp. 173-181.

— (2012): "El legado del exilio de Cristina Peri Rossi: un mapa para géneros e identidades". En: A Contracorriente. A Journal on Social History and Literature in Latin America, vol. 10, n. ${ }^{\circ} 1$, pp. 59-87. http://tools.chass.ncsu.edu/open_journal/index.php/ acontracorriente/article/view/625). Última visita: 20.08.2012.

Ortega, Julio (1992): El discurso de la abundancia. Caracas, Monte Ávila.

Peri Rossi, Cristina (1993): Cristina Peri Rossi. Málaga, Centro Cultural de la Generación del 27.

- (2003): Estado de exilio. Madrid, Visor.

- (2005): Poesía reunida. Barcelona, Lumen.

- (2008): La tarde del dinosaurio. Zaragoza, Tropo Editores.

Rama, Ángel (1966): "Raros y malditos en la literatura uruguaya". En: Marcha, n. 1319, pp. 30-31.

- (1972): La generación crítica 1939-1969. Montevideo, Arca.

Redondo Goicochea, Alicia (2001): "Para un catálogo de las escritoras españolas de cuentos en castellano en los años noventa". En: Romera Castillo, José y Gutiérrez Carbajo, Francisco (eds.): El cuento en la década de los noventa. Madrid, Visor, pp. 151-166.

Roas, David (2011): Tras los límites de lo real. Una definición de lo fantástico. Madrid, Páginas de Espuma.

Rosenblat, María Luisa (1990): Poe y Cortázar. Lo fantástico como nostalgia. Caracas, Monte Ávila.

San Román, Gustavo (1992): "Entrevista a Cristina Peri Rossi". En: Revista Iberoamericana, n. ${ }^{\circ} 160-161$, pp. 1041-1048. 
Todorov, Tzvetan (1972): Introducción a la literatura fantástica. Buenos Aires, Tiempo Contemporáneo.

Vax, Louis (1973): Arte y literatura fantásticas. Buenos Aires, Eudeba.

Verani, Hugo J. (1984): "La rebelión del cuerpo y el lenguaje (A propósito de Cristina Peri Rossi)". En: Quervo Poesía, monográfico n. ${ }^{\circ}$ 7, pp. 26-35.

Yurkievich, Saúl (1978): La confabulación con la palabra. Madrid, Taurus. 